knowu mammals from the rich deposits of Patagonia, Dr Simpson's work cannot fail to become the basis of all future study in this field and provide stimulation for further research.

S. C. CoRYNDON

\section{WALLS AND MEMBRANES}

\section{Cell Wails and Membranes}

By H. J. Rogers and H. R. Perkins. Pp. $\mathrm{x}+436$. (London: E. and F. N. Spon, Ltd; New York: Barnes and Noble, 1968.) 75s. net.

As the details of the replication processes of the cell are becoming revealed by advances in molecular biology, so attention is increasingly turning to problems associated with cell organization. A greater part of the organization of cells appears to be determined by the cell membrane and so many scientists are now becoming engaged on the problem of the structure and the mode and function of cell membranes. In some cases, for example, Grampositive bacteria, there is also a separate entity callod the cell wall outside the cell membrane. In other cases, for example, the majority of the Gram-negative bacteria, a clear cut distinction between the cell membrane and the cell wall is not possible.

The authors of this book have set out to describe the structure, functions and biosynthesis of the outer layors of the cells of living material including cell walls and membranes. The emphasis in the book is on their chemistry and biochemistry and, as far as possible, at the molecular level. The physical aspects which are most important for discussions at the molecular biological level, unfortunately, are given limited treatment. Chapters are included on the cell walls of algae, yeast, fungi and bacteria. The structure and biosynthesis of cell walls and components are dealt with in a comprehensive and upto-date manner.

The book appears to suffer from certain unbalance in that bacterial cell walls and envelopes are its major topic, while animal cell membranes and plant cell walls play a much less significant part in the book. A very short section is devoted to problems of solute transport across cell membranes. The selective permeability of membranes is discussed only briefly, and little space is devoted to permeases, notwithstanding the fact that Cohen and Monod first demonstrated their existence some eleven or twelve years ago. Some mention is made of model membrane systems of the black film and globular type, but this is an extremely short treatment.

With regard to the organization of the book, I would have preferred the first two or three chapters to have started with a discussion of the architecture of the cell wall and cell membranes, later followed by discussions of the physical and chemical properties of the components rather than the other way round. This may, however, be a personal preference. The first three chapters of the book discuss the chemical and physical properties of cellulose, the hemicelluloses, pectins and the lignins, respectively, before the architecture of the cell is described.

The book, however, is written in a clear style and covers very well the topics of the outer layers of bacterial yeasts and algae with a most valuable section on the biosynthesis of mucopeptides.

D. Chapman

\section{EXPERIMENTAL PSYCHOLOGY}

\section{Experimental Psychology}

Its Scope and Method. Edited by Paul Fraisse and Jcan Piaget. Vol. 1: History and Method. By Jean Piaget, Paul Fraisse and Maurice Reuchlin. Translated by Judith Chambers. Pp. ix +245 . Vol. 5: Motivation, Emotion and Personality. By Joseph Nuttin, Paul Fraisse and Richard Meili. Pp. v +289. (London: Routledge and Kegan Paul, Ltd, 1968) 35s. net each volume.
Thi French publishers, Presses Universitaires de France, have produced a nine-volume work on experimental psychology, broadly conceived, under the joint editorship of Professors Fraisso and Piaget. Volume 1, conecrned with the history and method of experimental psychology, first appeared in 1963 in French. It consists of the following four chapters: "The Evolution of Experimental Psychology" and "The Fxperimental Method", by Paul Fraisse, "Explanation in Psychology and Psychophysiological P'arallelism", by Jean Piaget, and "Measurement in Psychology", by Maurice Reuchlin. The only other volume that has so far come out in English is volume 5, which also goes back to 1963 . This book consists of three chapters: "Motivation", by Joseph Nuttin, "The Emotions", by Paul Fraisse, and "The Structure of the Person. ality", by Richard Meili.

In the first chapter of volume 1, Fraisse acknowledges his indebtedness to Boring's History of Experimental Psychology. Rather more than half the references quoted are works in English, and this reliance on English-language sources is, on the whole, a feature of both the present volumes. The historical chapter covers well-known ground, but the survey is very readable, and it is interest ing to look at the development of the subject as it is seen in France. The second chapter begins with a little philosophy of science, but soon moves on to problems of exporimental design, and especially controls and statistical inference. All the main issues arising in experimentation are surveyed. The last chapter deals with the important matter of measurement in psychology. The framework is provided by Stevens's classification of scales into ratio, interval, ordinal and nominal ones. The ground is covered systematically and the exposition is clear.

The third chapter in volume 1 is rather different in character, and may be described as an essay of theoretical interest. Piaget, as often before, sees order in seeming confusion. He points to certain stages in every research endeavour. But, above all, he classifies and analyses the full range of existing forms of psychological explanation, grouping the different psychological theories into appropriate categories. Piaget also re-examines the mind-body issue or, as he prefers it, the problem of "consciousness and the underlying physiological structures", and he re-formulates it in relation to views of explanation in psychology. This chapter is not so much a contribution to experimental psychology as to that branch of the philosophy of science which concerns itself with psychology. It presupposes in the reader a great deal of prior knowledge of psychology, and might have been better placed at the end of the series of volumes rather than near the beginning; but it would be churlish to complain.

The first chapter in volume 5 starts with the consideration of the topic of motivation in relation to experimental psychology, and then proceeds to survey all the traditional material found in books under the heading of motivation. It relies heavily on studies found in American learned journals; but references to British, German and French work give balance to the useful review and discussion. The second chapter on the emotions is equally informative and well documented. It provides a valuable review of the main experimental findings in this field of psychology. The last chapter of the volume deals with personality. Agxin there are more references to English-language publications than to French and German ones put to. gether. Nevertheless, this survey of personality studies has, perhaps, a more continental flavour than the many existing ones available in English.

The two volumes, although not absolutely up to date, present in a concise manner modern thought and developments in those fields of Western psychology which they set out to cover. Their readability has, no doubt, much to do with the skill of the translators. It is to be hoped that the remaining seven volumes will be published in English without undue delay.
W. StuCKIN 